\title{
Effects of Psychrotrophic Bacteria, Serratia liquefaciens and Acinetobacter genomospecies 10 on Yogurt Quality
}

\author{
Yong Kook Shin ${ }^{1}$, Nam Su Oh${ }^{1}$, Hyun Ah Lee ${ }^{1}$, Jong-Woo Choi², and Myoung Soo Nam* \\ Department of Animal Biosystem Science, Chungnam National University, Daejeon 305-764, Korea \\ ${ }^{1}$ Institute of Dairy Food Research, Seoul Dairy Co-op., Ansan 425-839, Korea \\ ${ }^{2}$ National Institute of Animal Science, Rural Development Administration, Suwon 441-706, Korea
}

\begin{abstract}
The aim of this study was to evaluate the effect of proteolytic (Serratia liquefaciens, match \%: 99.39) or lipolytic (Acinetobacter genomospecies 10, match \%: 99.90) psychrotrophic bacteria (bacterial counts, analysis of free fatty acids (FFA) and analysis of free amino acids) on the microbial and chemical properties (yogurt composition), and sodium dodecyl sulfate polyacrylamide gel electrophoresis (SDS-PAGE) of yogurt during storage. Yogurts were prepared with raw milk preinoculated with each psychrotrophic bacteria. The total solid, fat, and protein content were not affected by preinoculation, but the $\mathrm{pH}$ of yogurt preinoculated with psychrotrophic bacteria was higher than in control. There was a dramatic increase in short chain free fatty acids among FFA in yogurt with Acinetobacter genomospecies 10. For $14 \mathrm{~d}$ of cold storage condition, SCFFA was $25.3 \mathrm{mg} / \mathrm{kg}$ to $34.4 \mathrm{mg} / \mathrm{kg}$ (1.36 times increased), MCFFA was $20.4 \mathrm{mg} / \mathrm{kg}$ to $25.7 \mathrm{mg} / \mathrm{kg}$ (1.26 times increased), and LCFFA was $240.2 \mathrm{mg} / \mathrm{kg}$ to $322.8 \mathrm{mg} / \mathrm{kg}$ (1.34 times increased). Serratia liquefaciens (match \%: 99.39) in yogurt caused a greater accumulation of free amino acids (FAA), especially bitter peptides such as leucine, valine, arginine, and tyrosine, but SDS-PAGE showed that the inoculation of Serratia liquefaciens did not affect the degree of casein degradation during storage. Taken together, the excessive peptides and FFA in yogurt generated from psychrotrophic bacteria could develop off-flavors that degrade the quality of commercial yogurt products.
\end{abstract}

Keywords: psychrotrophic bacteria, Serratia liquefaciens, Acinetobacter genomospecies 10, free fatty acids, free amino acids

\section{Introduction}

Psychrotrophic bacteria is defined as the microorganisms that are able to grow at $7^{\circ} \mathrm{C}$ or less even if their optimum growth temperature is about $30^{\circ} \mathrm{C}$ (Ingraham, 1962; Ingraham and Stokes, 1959; Stokes, 1963; Thomas, 1966; Thomas and Thomas, 1973; Witter, 1961). There are a wide variety of genera and species of the family, such as Pseudomonas, Flavobacterium, and Alcaligenes spp. (Mikolajcik, 1979; Wessels et al., 1988), but little is known about the occurrence and significance of psychrotrophic coliform bacteria and other Enterobacteriaceae in milk and dairy products (Wessels et al., 1988). As dairy products are stored at refrigerated temperature for longer shelf life, the control of psychrotrophic bacteria has become progressively more significant in the dairy industry. The

*Corresponding author: Myoung Soo Nam, Department of Animal Biosystem Science, Chumngnam National University, Daejeon 305-764, Korea. Tel: +82-42-821-5782, Fax: +82-42-8232766, E-mail: namsoo@cnu.ac.kr pasteurization process can destroy the psychrotrophic bacteria that grow in raw milk during the refrigerated storage, but the extracellular enzymes, proteases and lipases, are heat-resistant and deteriorate the quality of dairy products because their activities remain even after ultrahigh temperature (UHT) treatment (Bigalke, 1985; Cousin, 1982; Stead, 1986). The proteases were related to the stability of casein, losses in cheese yield, and formation of off-flavors, while the residual activities of lipases resulted in rancid and fruity flavors from produced free fatty acids (Bigalke, 1985; Iwasaki and Kosikowski, 1973).

In previous report (Shin et al., 2013), we investigated the distribution of psychrotrophic bacteria. Raw milk was collected from farms in different regions of Kyunggi in South Korea over seasons, and the most lipolytic species Acinetobacter genomospecies 10 (match \%: 99.90) and the most proteolytic species Serratia liquefaciens (match $\%$ : 99.39) were isolated. In our experiment, we decided to treat raw milk with two psychrotrophic bacteria to see how quality of yogurt is affected. The aim of this study was to determine the effects of Acinetobacter genomo- 
species 10 (match \%: 99.90) and Serratia liquefaciens (match \%: 99.39) on microbial, lipolytic, and proteolytic properties of yogurt products.

\section{Materials and Methods}

\section{Yogurt preparation}

Raw milk was obtained from Seoul Dairy Cooperative, Korea. To investigate the effect of psychrotropic bacteria, raw milk was preinoculated with Acinetobacter genomospecies 10 or Serratia liquefaciens at $1 \times 10^{5} \mathrm{CFU} / \mathrm{mL}$, and incubated for 3 and $6 \mathrm{~d}$ at $7^{\circ} \mathrm{C}$ prior to the manufacture of yogurt. Yogurt mix was prepared by adding 2,357.2 $\mathrm{g}$ of inoculated milk to $51.7 \mathrm{~g}$ of skim milk powder (Vreugdenhii, Holland), $8.3 \mathrm{~g}$ of whey protein concentrate (Arla Foods, Denmark) and $82.8 \mathrm{~g}$ of fructooligosaccharide (CJ Cheiljedang, Korea). Yogurt mix was then pasteurized at $85^{\circ} \mathrm{C}$ for $10 \mathrm{~min}$ and cooled to $41^{\circ} \mathrm{C}$ in a temperaturecontrolled water bath. Starter cultures were added to cooled yogurt mix, which was incubated at $31^{\circ} \mathrm{C}$ for $5 \mathrm{~h}$. The desired final $\mathrm{pH}$ of the product was 4.7. Starter cultures used were purchased from Christian Hansen, Denmark; ABY-3 included Streptococcus thermophilus, Lactobacillus delbrueckii subsp. bulgaricus, Lactobacillus acidophilus, and Bifidobacterium animalis subsp. lactis BB-12.

\section{Composition analysis}

Yogurt was ground and analyzed in triplicate for moisture, ash, fat, and total protein using Association of Analytical Communities Official Methods (AOAC, 2007). For total protein analysis, an Automatic Kjeldahl System (Digestion system K-431 and Distillation Unit K-350; BUCHI Labortechnik AG, Switzerland) was used. The yogurt composition was analyzed at the beginning of and at the end of storage (after $14 \mathrm{~d}$ ).

\section{Bacterial counts}

Lactic acid bacteria counts were carried out in triplicate after $0,1,2,3,4$, and $5 \mathrm{~h}$ fermentation periods. Samples were diluted with sterile saline solution and plated on sterile BCP agar (Eiken Chemical Co., Japan) at $37^{\circ} \mathrm{C}$ for $3 \mathrm{~d}$.

\section{Determination of free fatty acids (FFA)}

FFA in samples were analyzed using GC-FID (Agilent, USA) according to the method of Jong and Badings (De Jong and Badings, 1990). After each stage of storage, samples were taken from yogurt at $5^{\circ} \mathrm{C}$ and then were stored at $-80^{\circ} \mathrm{C}$ pending analysis. The $1.0 \mathrm{~g}$ of yogurt was homogenized with $3 \mathrm{~g}$ anhydrous $\mathrm{Na}_{2} \mathrm{SO}_{4}, 0.3 \mathrm{~mL} \mathrm{H}_{2} \mathrm{SO}_{4}$ $(2.5 \mathrm{~mol} / \mathrm{L})$, and $1.0 \mathrm{~mL}$ of enanthic acid (C7:0) and margaric acid (C17:0) was added as internal standard. Lipids were extracted three times with $3 \mathrm{~mL}$ ether/heptane $(1: 1$, $\mathrm{v} / \mathrm{v}$ ) by centrifugation $(2,500 \mathrm{rpm}, 5 \mathrm{~min})$.

Isolation of the FFA was achieved with the anion-

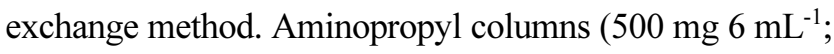
Waters, USA) were conditioned with $10 \mathrm{~mL}$ heptane. The lipid extract was applied to the column. The neutral lipids were eluted from the column with chloroform/2-propanol $(2: 1, v / v)$. The FFA were eluted with diethyl ether containing $2 \%$ formic acid. A sample $(1 \mu \mathrm{L})$ was injected into GC for the determination of the FFA.

A capillary column $(25 \mathrm{~m} \times 0.32 \mathrm{~mm}$ i.d. $)$ coated with FFAP ( $\mathrm{df}=0.3 \mu \mathrm{m}, \mathrm{J} \& \mathrm{~W}$ Scientific, USA) was used, and the carrier gas (nitrogen) flow rate was $2 \mathrm{~mL} / \mathrm{min}$. The oven temperature was programmed to go from $65^{\circ} \mathrm{C}$ to $240^{\circ} \mathrm{C}$ at a rate of $10^{\circ} \mathrm{C} / \mathrm{min}^{-1}$. The FID temperature was $250^{\circ} \mathrm{C}$. Peak identities were determined based on retention times of standard compounds and concentrations of individual fatty acids were quantified by using a standard curve for each compound, relating peak area to the concentration. Samples were taken from yogurt products at 1 , 7 , and $14 \mathrm{~d}$ of storage and were stored at $-60^{\circ} \mathrm{C}$ until analysis.

\section{Determination of free amino acids (FAA)}

Analysis of the FAA was carried out according to the AQC-precolumn derivatization procedure as described by Hong (1994). All separation was made by HPLC system (Waters Alliance, USA) conducted on a Nova-Pak C18 $(4 \mu \mathrm{m})$ column (Waters) at $37^{\circ} \mathrm{C}$, and operated with a flow rate of $1.0 \mathrm{~mL} / \mathrm{min}$. The linear gradient elution system was used. Mobile phases A, B, and C were acetatephosphate buffer solution, acetonitrile, and water, respectively. The excitation and emission wavelengths for the fluorescence detector were $250 \mathrm{~nm}$ and $395 \mathrm{~nm}$, respectively. The gain setting of the detector was 10 . Samples were taken from yogurt products at 1,7 , and $14 \mathrm{~d}$ of storage and were stored at $-60^{\circ} \mathrm{C}$ until analysis.

\section{Sodium dodecyl sulfate polyacrylamide gel electro- phoresis (SDS-PAGE)}

SDS-PAGE was carried out according to the stacking gel procedure as described by Laemmli (1970). Protein concentration was quantified using a Synergy H1 plate reader (Bio-Tek Instruments, Inc., USA) with the take microdrop addition. Each sample was redissolved in SDSPAGE sample buffer [62.5 mM Tris-HCl, pH 6.8; 2\% (w/ 
v) SDS; $25 \%(\mathrm{v} / \mathrm{v})$ glycerol; $5 \%(\mathrm{v} / \mathrm{v})$ 2-mercaptoethanol; $0.01 \%(\mathrm{w} / \mathrm{v})$ bromophenol blue] and denatured at $100^{\circ} \mathrm{C}$ for $5 \mathrm{~min}$. Twenty micrograms of the samples were loaded on $10 \%$ Ready Gel (Tris-HCl Gel, Bio-Rad, Hercules, USA). The equipment employed was the Mini-PROTEAN $^{\circledR}$ Tetra Cell (Bio-Rad). The gels were stained with Coomassie Brilliant Blue R-250 Staining Solution (BioRad). Destaining was carried out with a Coomassie Brilliant Blue R-250 Destaining Solution (Bio-Rad).

\section{Statistical analysis}

All data were subjected to one-way analysis of variance (ANOVA). Significant differences among means of replicates $(n=3)$ were determined by Duncan's multiple range tests. The SAS statistical software package was used to perform all statistical tests (SAS Inst., 2010). Values of $p$ $<0.05$ were considered to indicate a significant difference.

\section{Results and Discussion}

\section{Effect of Acinetobacter genomospecies 10 on yogurt lipolysis}

\section{Yogurt Compositions}

The composition of yogurt prepared from raw milk preinoculated with or without Acinetobacter genomospecies 10 during storage is shown in Table 1. No significant difference was observed in the total solid and fat content over $14 \mathrm{~d}$ at $5^{\circ} \mathrm{C}$.

Changes of $\mathrm{pH}$ and starter lactic bacterial counts (SLAB)

The changes in $\mathrm{pH}$ value and viable counts of starter lactic acid bacteria (SLAB) in different yogurts during fermentation are presented in Figs. 1A and 2A. The $\mathrm{pH}$ values at the end of fermentation $(5 \mathrm{~h})$ of yogurt made with raw milk preincubated for 3 (YA3) and 6 (YA6) days
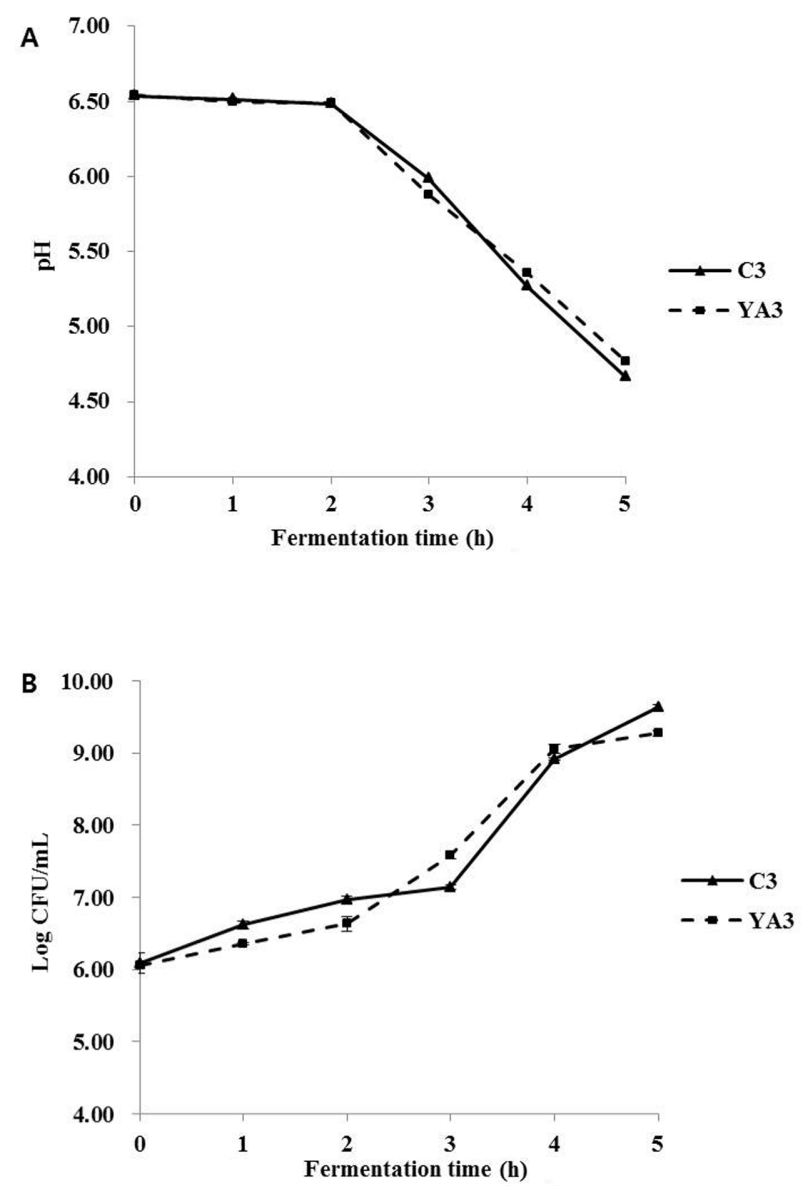

Fig. 1. The $\mathbf{p H}$ value and counts of starter lactic acid bacteria of yogurt made with $3 \mathrm{~d}$ refrigerated raw milk (YA3) by fermentation time. $\mathrm{C} 3$; yogurt made by uninoculated raw milk during $3 \mathrm{~d}$, YA3; yogurt made by inoculated raw milk during $3 \mathrm{~d}$ with Acinetobacter genomospecies 10 (match \%:99.90).

after preinoculation were 4.77 and 4.66 , respectively. Observed $\mathrm{pH}$ values for yogurt made with raw milk preincubated for $3(\mathrm{C} 3)$ and $6(\mathrm{C} 6)$ days with uninoculation were 4.66 and 4.67 , respectively. The difference in $\mathrm{pH}$ values affected by preinoculation with psychrotrophic bacteria is

Table 1. Compositional concentrations of yogurt made with 6 days-refrigerated raw milk after inoculation

\begin{tabular}{cccc}
\hline \hline & Composition (\%) & $0 \mathrm{~d}$ & $14 \mathrm{~d}$ \\
\hline \multirow{3}{*}{ Control (C6) } & Total solid & $17.04^{\mathrm{a}} \pm 0.06$ & $16.92^{\mathrm{b}} \pm 0.02$ \\
& Fat & $3.78^{\mathrm{a}} \pm 1.57$ & $3.76^{\mathrm{a}} \pm 0.33$ \\
& Protein & $3.89^{\mathrm{a}} \pm 0.41$ & $3.82^{\mathrm{a}} \pm 0.74$ \\
\hline \multirow{2}{*}{ Sample (YA6) } & Total solid & $17.06^{\mathrm{a}} \pm 0.04$ & $16.96^{\mathrm{b}} \pm 0.04$ \\
& Fat & $3.73^{\mathrm{a}} \pm 0.61$ & $3.72^{\mathrm{a}} \pm 0.14$ \\
& Protein & $3.88^{\mathrm{a}} \pm 0.97$ & $3.86^{\mathrm{a}} \pm 2.90$ \\
\hline
\end{tabular}

$\overline{\mathrm{a}, \mathrm{b}}$ Means with different superscripts within same rows are significantly different, $p<0.05$.

Values were expressed as mean \pm standard deviation $(n=3)$.

C6 : yogurt made by uninoculated raw milk during $6 \mathrm{~d}$.

YA6 : yogurt made by inoculated raw milk during $6 \mathrm{~d}$ with $1 \times 10^{5} \mathrm{CFU} / \mathrm{mL}$ of Acinetobacter genomospecies 10 (match \%:99.90). 

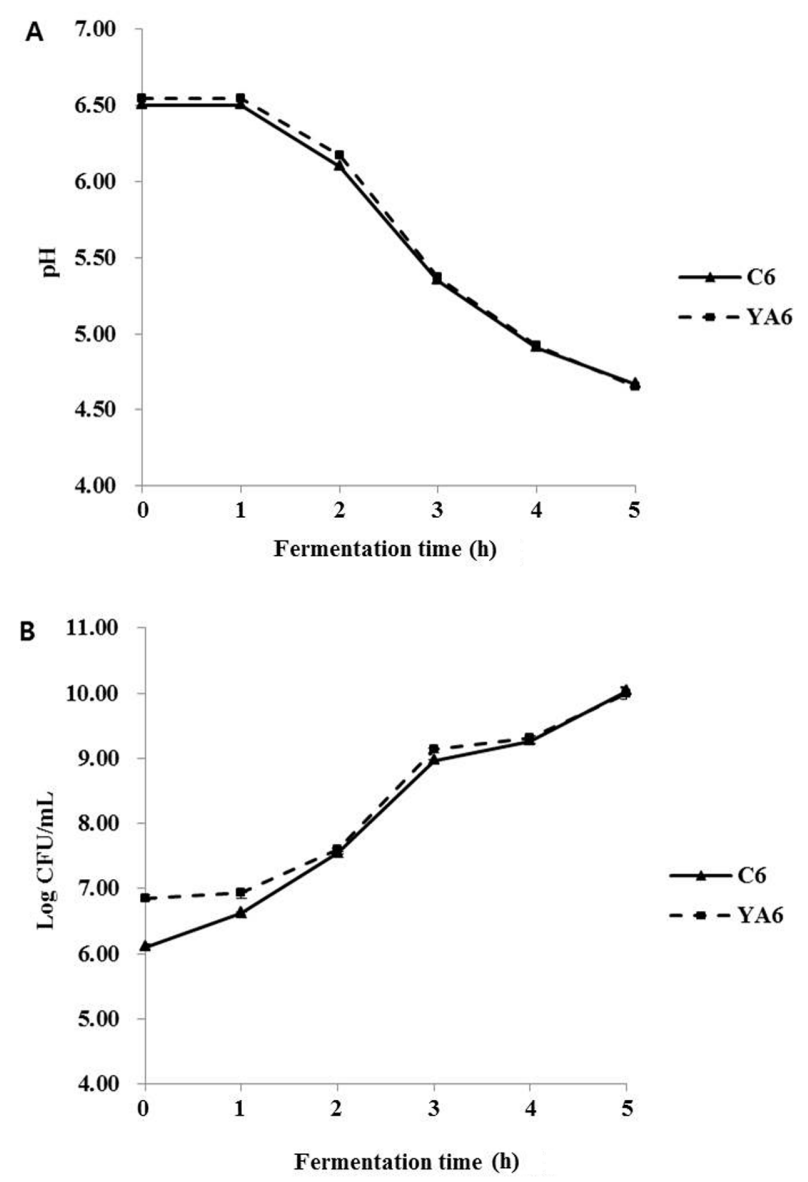

Fig. 2. The pH value and counts of starter lactic acid bacteria of yogurt made with $6 \mathrm{~d}$ refrigerated raw milk (YA6) by fermentation time. $\mathrm{C} 6$; yogurt made by uninoculated raw milk during $6 \mathrm{~d}$, YA6; yogurt made by inoculated raw milk during $6 \mathrm{~d}$ with Acinetobacter genomospecies 10 (match \%:99.90).

thus negligible.

The bacterial counts of SLAB in C3 ranged from 6.09 to $9.64 \mathrm{Log} \mathrm{CFU} / \mathrm{mL}$, and this seems similar to those in YA3 (Fig. 1B). In addition, the corresponding figures in YA6 and C6 varied from 6.10 to 10.02 , and from 6.0 to $10.02 \mathrm{Log} \mathrm{CFU} / \mathrm{mL}$, respectively. Although YA6 exhibited higher counts of SLAB compared to C6 in the early stage of fermentation, YA6 and C6 gave almost identical counts of SLAB after $4 \mathrm{~h}$ fermentation (Fig. 2B). This indicated that lipase produced by Acinetobacter genomospecies 10 did not significantly affect the counts of SLAB in yogurt manufacturing.

\section{Free fatty acids (FFA) analysis}

Tables 2 and 3 present the FFA content of different yogurt stored at $5^{\circ} \mathrm{C}$ for $14 \mathrm{~d}$. Fat content in yogurt did not change as shown in Table 1, but the amount of each FFA did change. The concentration of total FFA (sum of C4:0 to C18:2) in YA3 was $286.0 \mathrm{mg} / \mathrm{kg}$ at day 0 and $14 \mathrm{~d}$ later increased greatly to $382.9 \mathrm{mg} / \mathrm{kg}$. When the storage of yogurts (YA3) was extended to $14 \mathrm{~d}$ at $5{ }^{\circ} \mathrm{C}$, short chain FFA (SCFFA, sum of $\mathrm{C} 4: 0$ to $\mathrm{C} 8: 0$ ), medium chain FFA (MCFFA, sum of C10:0 to C12:0), and long chain FFA (LCFFA, sum of C14:0 to C18:2) were increased ( $p<$ 0.05 ) from 25.3 to 34.4 (1.36 times increased), from 20.4 to 25.7 (1.26 times increased), and from 240.2 to 322.8 $\mathrm{mg} / \mathrm{kg}$ (1.34 times increased), respectively. However, the early stage total FFA content of C3 was $204.7 \mathrm{mg} / \mathrm{kg}$ and $14 \mathrm{~d}$ later, it increased to $238.9 \mathrm{mg} / \mathrm{kg}$. A higher rate of increased concentration of total FFA was therefore, observed in YA3 compared to $\mathrm{C} 3(p<0.05)$. Butyrate $(\mathrm{C} 4: 0)$, palmitate (C16:0), and oleate (C18:1) contents in YA3 were 2.4 times, 1.7 times, and 1.7 times higher than in control, respectively.

Total FFA content in YA6 was $369.5 \mathrm{mg} / \mathrm{kg}$ at $0 \mathrm{~d}$ and increased to $390.9 \mathrm{mg} / \mathrm{kg}$ at $14 \mathrm{~d}$. In contrast to YA3, SCFFA and MCFFA content were greatly increased, but LCFFA was not $(p<0.05)$. For $14 \mathrm{~d}$ of cold storage, an increase in SCFFA was 1.1 times from 32.5 to 35.6 , and in MCFFA was 1.2 times from 22.3 to $26.0 \mathrm{mg} / \mathrm{kg}$. The initial concentration of total FFAs in C6 was 269.3, and was peaked to $298.0 \mathrm{mg} / \mathrm{kg}$ at $7 \mathrm{~d}$, which thereafter did not increase until the end of storage. Hence, the SCFFA, MCFFA, and LCFFA content in YA6 were higher than in C6; in particular, butyrate (C4:0) and palmitate (C16:0) were relatively higher than in $\mathrm{C} 6$.

Lipolysis in milk and dairy products results from the hydrolysis of triacylglycerols by lipases. The degree of lipase production by psychrotrophic bacteria generally varies from species to species, and depends on the storage conditions, temperature, and $\mathrm{pH}$ (Cousin, 1982; Shelley et al., 1986). One of the most important properties of these bacterial lipases is their heat stability; most of them retain at least some of their activity after pasteurization or even after UHT treatment (Serra et al., 2008). However, lipolysis tends normally to cause few problems in yogurt due to a combination of factors: low $\mathrm{pH}$, low storage temperatures, relatively short shelf life, and high normal flavor level (Deeth, 2002). In this study, Acinetobacter genomospecies 10 was strongly involved in the degradation of the fat in yogurt made from raw milks during cold storage. The lipase that was excreted from Acinetobacter genomospecies 10 contributed to the production of SCFFA and LCFFA. 
Table 2. Concentrations of free fatty acid in yogurt made with 3 days-refrigerated raw milk after inoculation

\begin{tabular}{|c|c|c|c|c|}
\hline & Fatty acid (mg/kg yogurt) & $0 \mathrm{~d}$ & $7 \mathrm{~d}$ & $14 \mathrm{~d}$ \\
\hline \multirow{14}{*}{ Control } & $\mathrm{C} 4: 0$ & $6.3^{\mathrm{a}} \pm 0.0$ & $6.6^{b} \pm 0.0$ & $7.0^{\mathrm{c}} \pm 0.0$ \\
\hline & C6:0 & $5.4^{\mathrm{a}} \pm 0.0$ & $5.7^{\mathrm{b}} \pm 0.1$ & $5.9^{c} \pm 0.0$ \\
\hline & $\mathrm{C} 8: 0$ & $5.7^{\mathrm{a}} \pm 0.0$ & $5.9^{\mathrm{a}} \pm 0.1$ & $6.3^{\mathrm{b}} \pm 0.1$ \\
\hline & C10:0 & $7.6^{\mathrm{a}} \pm 0.1$ & $8.0^{\mathrm{b}} \pm 0.1$ & $9.0^{\mathrm{c}} \pm 0.1$ \\
\hline & C12:0 & $7.4^{\mathrm{a}} \pm 0.1$ & $8.1^{\mathrm{b}} \pm 0.1$ & $9.2^{\mathrm{c}} \pm 0.1$ \\
\hline & C14:0 & $12.0^{\mathrm{a}} \pm 0.1$ & $13.3^{\mathrm{b}} \pm 0.7$ & $15.1^{\mathrm{c}} \pm 0.2$ \\
\hline & $\mathrm{C} 16: 0$ & $70.0^{\mathrm{a}} \pm 1.1$ & $74.3^{\mathrm{a}} \pm 6.2$ & $69.7^{\mathrm{a}} \pm 5.2$ \\
\hline & C18:0 & $44.4^{\mathrm{a}} \pm 1.5$ & $52.1^{\mathrm{b}} \pm 2.4$ & $47.6^{\mathrm{ab}} \pm 2.4$ \\
\hline & C18:1 & $37.8^{\mathrm{a}} \pm 1.3$ & $46.3^{\mathrm{b}} \pm 4.5$ & $57.3^{\mathrm{c}} \pm 3.2$ \\
\hline & C18:2 & $8.1^{\mathrm{a}} \pm 0.1$ & $10.0^{\mathrm{b}} \pm 0.6$ & $12.0^{c} \pm 0.5$ \\
\hline & SCFFA & $17.4^{\mathrm{a}} \pm 0.0$ & $18.1^{\mathrm{b}} \pm 0.1$ & $19.2^{\mathrm{c}} \pm 0.1$ \\
\hline & MCFFA & $15.0^{\mathrm{a}} \pm 0.0$ & $16.1^{\mathrm{b}} \pm 0.2$ & $18.2^{\mathrm{c}} \pm 0.2$ \\
\hline & LCFFA & $172.2^{\mathrm{a}} \pm 3.3$ & $196.0^{\mathrm{b}} \pm 14.3$ & $201.6^{\mathrm{b}} \pm 11.1$ \\
\hline & Total FFA & $204.7^{\mathrm{a}} \pm 3.3$ & $230.2^{\mathrm{b}} \pm 14.4$ & $238.9^{\mathrm{b}} \pm 11.3$ \\
\hline \multirow{14}{*}{ YA3 } & $\mathrm{C} 4: 0$ & $10.6^{\mathrm{a}} \pm 0.5$ & $12.7^{\mathrm{a}} \pm 0.1$ & $16.7^{\mathrm{b}} \pm 1.7$ \\
\hline & C6:0 & $7.3^{\mathrm{a}} \pm 0.1$ & $8.6^{\mathrm{b}} \pm 0.1$ & $8.9^{\mathrm{b}} \pm 0.3$ \\
\hline & $\mathrm{C} 8: 0$ & $7.4^{\mathrm{a}} \pm 0.5$ & $8.8^{\mathrm{b}} \pm 0.1$ & $8.8^{\mathrm{b}} \pm 0.3$ \\
\hline & $\mathrm{C} 10: 0$ & $10.4^{\mathrm{a}} \pm 0.9$ & $11.5^{\mathrm{ab}} \pm 0.3$ & $12.6^{\mathrm{b}} \pm 0.2$ \\
\hline & $\mathrm{C} 12: 0$ & $10.0^{\mathrm{a}} \pm 0.5$ & $12.0^{\mathrm{b}} \pm 0.2$ & $13.2^{\mathrm{b}} \pm 1.0$ \\
\hline & C14:0 & $19.5^{\mathrm{a}} \pm 0.5$ & $25.3^{b} \pm 0.5$ & $27.0^{\mathrm{b}} \pm 2.4$ \\
\hline & C16:0 & $93.3^{\mathrm{a}} \pm 6.7$ & $113.7^{b} \pm 2.9$ & $119.2^{\mathrm{b}} \pm 10.8$ \\
\hline & C18:0 & $56.7^{\mathrm{a}} \pm 1.5$ & $66.7^{\mathrm{b}} \pm 2.2$ & $68.3^{\mathrm{b}} \pm 5.2$ \\
\hline & C18:1 & $60.9^{\mathrm{a}} \pm 2.7$ & $80.3^{\mathrm{b}} \pm 2.5$ & $95.1^{\mathrm{c}} \pm 7.0$ \\
\hline & C18:2 & $9.8^{\mathrm{a}} \pm 0.4$ & $11.7^{\mathrm{b}} \pm 0.3$ & $13.2^{\mathrm{b}} \pm 1.0$ \\
\hline & SCFFA & $25.3^{\mathrm{a}} \pm 0.2$ & $30.1^{\mathrm{b}} \pm 0.1$ & $34.4^{\mathrm{c}} \pm 1.7$ \\
\hline & MCFFA & $20.4^{\mathrm{a}} \pm 0.5$ & $23.5^{\mathrm{b}} \pm 0.1$ & $25.7^{\mathrm{c}} \pm 1.2$ \\
\hline & LCFFA & $240.2^{\mathrm{a}} \pm 11.3$ & $297.8^{\mathrm{b}} \pm 8.3$ & $322.8^{\mathrm{b}} \pm 25.4$ \\
\hline & Total FFA & $286.0^{\mathrm{a}} \pm 10.8$ & $351.4^{\mathrm{b}} \pm 8.4$ & $382.9^{\mathrm{b}} \pm 25.2$ \\
\hline
\end{tabular}

${ }_{\mathrm{a}, \mathrm{b}}$ Means with different superscripts within same rows are significantly different, $p<0.05$.

Values were expressed as mean \pm standard deviation $(n=3)$.

SCFFA = Short-chain FFA (sum of C4:0 to C8:0); MCFFA = medium-chain FFA (sum of C10:0 to C12:0); LCFFA = long-chain FFA (sum of C14:0 to C18:2); Total FFA (sum of C4:0 to C18:2).

\section{Effect of Serratia liquefaciens on proteolysis in yogurt}

\section{Yogurt compositions}

The compositions of yogurt pretreated with or without Serratia liquefaciens before preincubated for $14 \mathrm{~d}$ at $5^{\circ} \mathrm{C}$ are compared in Table 1. No significant effect was observed in the total solid and protein content of yogurts

\section{Changes of $\mathrm{pH}$ and starter lactic acid bacterial counts}

The changes in $\mathrm{pH}$ and the number of lactic acid bacteria were measured in YS3 and YS6. The $\mathrm{pH}$ value of YS3, which was inoculated with Serratia liquefaciens, was lower than of $\mathrm{C} 3$ for $3 \mathrm{~h}$ (Fig. 3A). The $\mathrm{pH}$ value of $\mathrm{Y} 3$ ranged from 6.29 to 5.07 and that of $\mathrm{C} 3$ ranged from 6.51 to 5.87. However, after $4 \mathrm{~h}$ fermentation, the $\mathrm{pH}$ of YS3, 4.94, was higher than of $\mathrm{C} 3,4.74$. The $\mathrm{pH}$ value of YS6 was lower than of $\mathrm{C} 6$ for up to $2 \mathrm{~h}$. From initial stage to $2 \mathrm{~h}$, the $\mathrm{pH}$ values of YS6 were changed from 6.22 to 6.35, and 6.19, and the $\mathrm{pH}$ values of $\mathrm{C} 6$ were from 6.79 to 6.69 and 6.43 (Fig. 4A). However, after $3 \mathrm{~h} \mathrm{pH}$ value in YS6 was higher than in C6. Therefore, it is thought that protease secreted from Serratia liquefaciens could affect the $\mathrm{pH}$ value in yogurts.

With regard to changes in the number of lactic acid bacteria during fermentation, the number in YS3 increased from 6.41 at the start of dermentation to $9.42 \mathrm{Log}$ $\mathrm{CFU} / \mathrm{mL}$ at $5 \mathrm{~h}$. In contrast, the lactic acid bacteria in $\mathrm{C} 3$ ranged from 6.46 to $9.67 \mathrm{Log} \mathrm{CFU} / \mathrm{mL}$ (Fig. 3B), which indicated that the lactic acid bacteria of YS3 was slightly lower than C3. Further, the lactic acid bacteria in YS6, which was inoculated with $5 \mathrm{Log} \mathrm{CFU} / \mathrm{mL}$ of psychrotrophic bacteria ranged from 6.25 to $9.50 \mathrm{Log} \mathrm{CFU} / \mathrm{mL}$ during $5 \mathrm{~h}$ fermentation, which did not significantly differ from to C6 (Fig. 4B). It is likely that inoculation of Ser- 
Table 3. Concentrations of free fatty acid in yogurt made with 6 days-refrigerated raw milk after inoculation

\begin{tabular}{|c|c|c|c|c|}
\hline & Fatty acid (mg/kg yogurt) & $0 \mathrm{~d}$ & $7 \mathrm{~d}$ & $14 \mathrm{~d}$ \\
\hline \multirow{14}{*}{ Control } & $\mathrm{C} 4: 0$ & $6.5^{\mathrm{a}} \pm 0.1$ & $7.3^{\mathrm{b}} \pm 0.1$ & $7.9^{c} \pm 0.3$ \\
\hline & C6:0 & $5.6^{\mathrm{a}} \pm 0.1$ & $6.1^{\mathrm{b}} \pm 0.1$ & $6.3^{\mathrm{b}} \pm 0.1$ \\
\hline & C8:0 & $6.1^{\mathrm{a}} \pm 0.0$ & $6.7^{\mathrm{b}} \pm 0.1$ & $6.7^{\mathrm{b}} \pm 0.1$ \\
\hline & $\mathrm{C} 10: 0$ & $8.7^{\mathrm{a}} \pm 0.1$ & $9.7^{\mathrm{b}} \pm 0.1$ & $10.4^{\mathrm{b}} \pm 0.4$ \\
\hline & $\mathrm{C} 12: 0$ & $8.2^{\mathrm{a}} \pm 0.2$ & $10.1^{\mathrm{b}} \pm 0.1$ & $10.0^{\mathrm{b}} \pm 0.6$ \\
\hline & $\mathrm{C} 14: 0$ & $14.2^{\mathrm{a}} \pm 0.1$ & $17.3^{\mathrm{b}} \pm 0.4$ & $16.9^{\mathrm{b}} \pm 1.2$ \\
\hline & $\mathrm{C} 16: 0$ & $78.9^{\mathrm{a}} \pm 1.1$ & $80.7^{\mathrm{a}} \pm 3.2$ & $72.4^{\mathrm{a}} \pm 6.0$ \\
\hline & $\mathrm{C} 18: 0$ & $56.1^{\mathrm{a}} \pm 1.5$ & $58.1^{\mathrm{a}} \pm 1.6$ & $56.4^{\mathrm{a}} \pm 4.7$ \\
\hline & C18:1 & $69.3^{\mathrm{a}} \pm 2.1$ & $84.5^{\mathrm{b}} \pm 1.6$ & $81.8^{\mathrm{b}} \pm 7.3$ \\
\hline & $\mathrm{C} 18: 2$ & $15.7^{\mathrm{a}} \pm 0.3$ & $17.6^{\mathrm{b}} \pm 0.3$ & $17.5^{\mathrm{b}} \pm 1.3$ \\
\hline & SCFFA & $18.2^{\mathrm{a}} \pm 0.1$ & $20.1^{\mathrm{b}} \pm 0.1$ & $20.9^{c} \pm 0.2$ \\
\hline & MCFFA & $16.9^{\mathrm{a}} \pm 0.3$ & $19.8^{\mathrm{b}} \pm 0.1$ & $20.4^{\mathrm{b}} \pm 0.6$ \\
\hline & LCFFA & $234.2^{\mathrm{a}} \pm 5.0$ & $258.1^{\mathrm{a}} \pm 4.7$ & $245.1^{\mathrm{a}} \pm 19.8$ \\
\hline & Total FFA & $269.3^{\mathrm{a}} \pm 4.7$ & $298.0^{\mathrm{b}} \pm 4.8$ & $286.5^{\mathrm{ab}} \pm 20.1$ \\
\hline \multirow{14}{*}{ YA6 } & $\mathrm{C} 4: 0$ & $18.4^{\mathrm{a}} \pm 0.6$ & $19.6^{\mathrm{ab}} \pm 0.2$ & $20.3^{\mathrm{b}} \pm 0.8$ \\
\hline & C6:0 & $7.0^{\mathrm{a}} \pm 0.0$ & $7.5^{\mathrm{b}} \pm 0.1$ & $7.7^{\mathrm{c}} \pm 0.1$ \\
\hline & C8:0 & $7.1^{\mathrm{a}} \pm 0.1$ & $7.6^{\mathrm{b}} \pm 0.1$ & $7.6^{\mathrm{b}} \pm 0.2$ \\
\hline & $\mathrm{C} 10: 0$ & $10.5^{\mathrm{a}} \pm 0.2$ & $11.1^{\mathrm{a}} \pm 0.2$ & $12.5^{\mathrm{b}} \pm 1.0$ \\
\hline & $\mathrm{C} 12: 0$ & $11.8^{\mathrm{a}} \pm 0.2$ & $13.2^{\mathrm{b}} \pm 0.3$ & $13.5^{\mathrm{b}} \pm 0.5$ \\
\hline & C14:0 & $27.6^{\mathrm{a}} \pm 0.3$ & $30.2^{\mathrm{a}} \pm 1.6$ & $30.4^{\mathrm{a}} \pm 1.6$ \\
\hline & C16:0 & $121.2^{\mathrm{a}} \pm 2.8$ & $132.4^{\mathrm{a}} \pm 7.6$ & $120.8^{\mathrm{a}} \pm 7.3$ \\
\hline & C18:0 & $67.5^{\mathrm{a}} \pm 2.5$ & $76.8^{\mathrm{b}} \pm 1.7$ & $72.2^{\mathrm{ab}} \pm 3.9$ \\
\hline & C18:1 & $86.5^{\mathrm{a}} \pm 3.0$ & $97.4^{\mathrm{a}} \pm 1.2$ & $93.3^{\mathrm{a}} \pm 6.9$ \\
\hline & C18:2 & $11.8^{\mathrm{a}} \pm 0.1$ & $12.7^{\mathrm{a}} \pm 0.8$ & $12.6^{\mathrm{a}} \pm 0.6$ \\
\hline & SCFFA & $32.5^{\mathrm{a}} \pm 0.7$ & $34.7^{\mathrm{a}} \pm 0.1$ & $35.6^{\mathrm{b}} \pm 0.8$ \\
\hline & MCFFA & $22.3^{\mathrm{a}} \pm 0.3$ & $24.3^{\mathrm{b}} \pm 0.4$ & $26.0^{\mathrm{c}} \pm 1.3$ \\
\hline & LCFFA & $314.7^{\mathrm{a}} \pm 8.6$ & $349.6^{\mathrm{a}} \pm 12.9$ & $329.3^{\mathrm{a}} \pm 20.2$ \\
\hline & Total FFA & $369.5^{\mathrm{a}} \pm 7.7$ & $408.6^{\mathrm{b}} \pm 13.2$ & $390.9^{a b} \pm 20.8$ \\
\hline
\end{tabular}

${ }^{\mathrm{a}, \mathrm{b}}$ Means with different superscripts within same rows are significantly different, $p<0.05$.

Values were expressed as mean \pm standard deviation $(n=3)$.

SCFFA $=$ Short-chain FFA (sum of C4:0 to C8:0); MCFFA = medium-chain FFA (sum of C10:0 to C12:0); LCFFA = long-chain FFA (sum of $\mathrm{C} 14: 0$ to $\mathrm{C} 18: 2$ ); Total FFA (sum of $\mathrm{C} 4: 0$ to $\mathrm{C} 18: 2$ ).

ratia liquefaciens could not inhibit the proliferation of SLAB during fermentation of yoghurt.

\section{Free amino acid (FAA) analysis}

Free amino acid analysis was performed to measure the degree of proteolysis in YS6 made with raw milk preinoculated with Serratia liquefaciens. As shown in SDSPAGE (Fig. 7), the level of preinoculation that was about $1 \times 10^{5} \mathrm{CFU} / \mathrm{mL}$ gave high proteolytic activity. The initial concentration of FAA in C6 and YS6 was 258.0 and 436.4 $\mathrm{mg} / \mathrm{kg}$, respectively, and after $14 \mathrm{~d}$ storage in YS6 was $743.4 \mathrm{mg} / \mathrm{kg}$, which was 1.7 times as high, and C6 was $339.2 \mathrm{mg} / \mathrm{kg}$, which was 1.3 times as high (Figs. 5 and 6). Thus, YS6 gave higher FAA than C6. This increase of FAA in YS6 indicates that the residual activity of the enzyme could survive after heat treatment at $85^{\circ} \mathrm{C}$, and cause the protein degradation. Adams et al. (1976) reported that $70-90 \%$ of the UHT treatment milk with psy- chrotrophic microbial proteases showed enzyme activity.

The highest concentration of FAA in YS6 at $1 \mathrm{~d}$ was a proline with $132.2 \mathrm{mg} / \mathrm{kg}$ and the decreasing order of individual FAA was threonine $>$ leucine $>$ lysine $>$ valine. In control (C6), threonine was $77.8 \mathrm{mg} / \mathrm{kg}$ and the decreasing order of individual FAA was proline $>$ arginine $>$ alanine. Proline with $151.8 \mathrm{mg} / \mathrm{kg}$ was also the highest amino acids among FAA in YS6 at $14 \mathrm{~d}$, and the decreasing order of concentration was arginine $>$ threonine $>$ leucine $>$ lysine. The arginine that has bitter taste was increased by about 10 times from 12.1 to $131.4 \mathrm{mg} /$ $\mathrm{kg}$. Moreover, hydrophobic bitter taste amino acid of tyrosine increased dramatically by about 4.9 times from 2.8 to $13.6 \mathrm{mg} / \mathrm{kg}$. The content of hydrophobic amino acids, phenylalanine, leucine, and lysine, in YS6 had a 10 times higher than in C6. It can be expected that yogurt inoculated with Serratia liquefaciens may have a serious sensory defect due to excessive release of FAA. The quality 

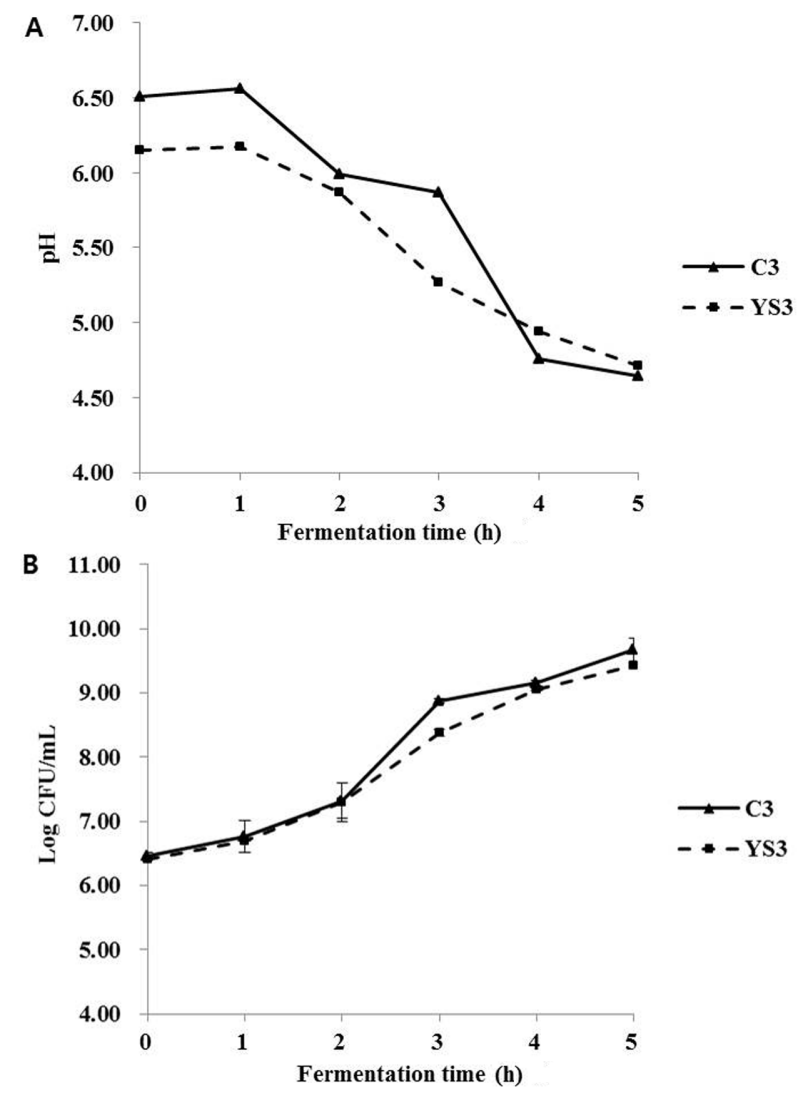

Fig. 3. The pH value and counts of starter lactic acid bacteria of yogurt made with 3 d refrigerated raw milk (YS3) by fermentation time. $\mathrm{C} 3$; yogurt made by uninoculated raw milk during $3 \mathrm{~d}$, YS3; yogurt made by inoculated raw milk during $3 \mathrm{~d}$ with Serratia liquefaciens (match \%: 99.39) as $10^{5} \mathrm{CFU} / \mathrm{mL}$.
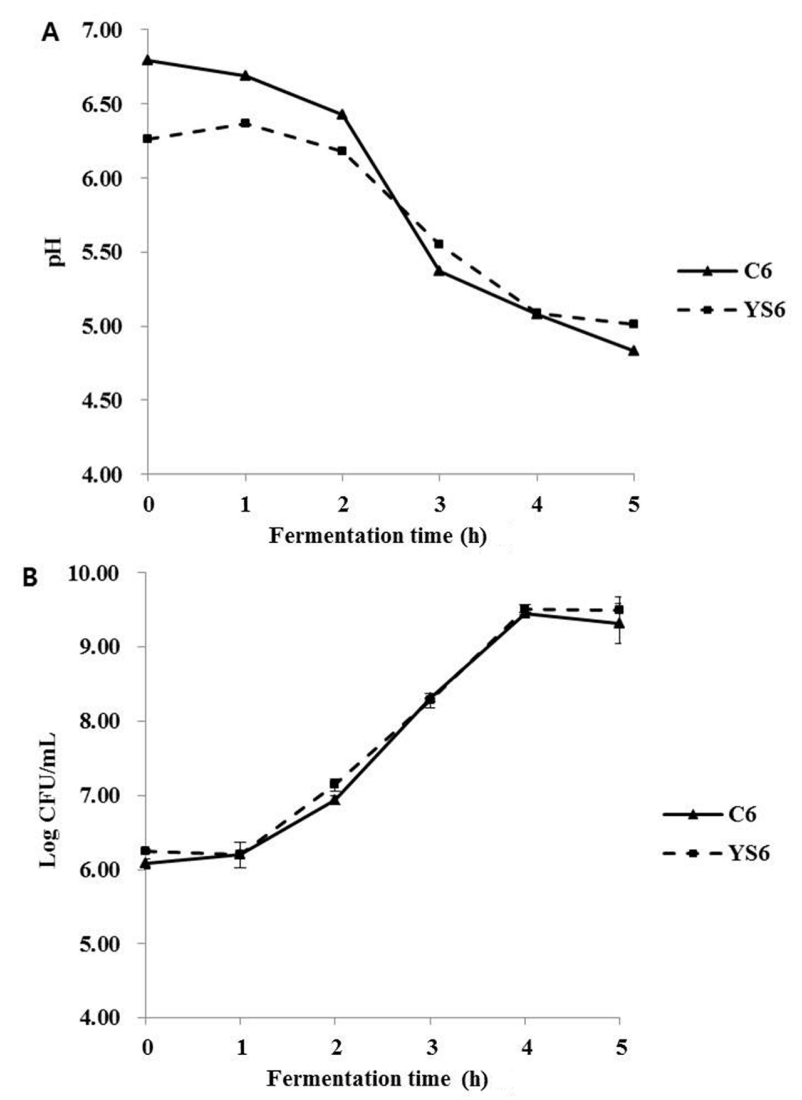

Fig. 4. The pH value and counts of starter lactic acid bacteria of yogurt made with $3 \mathrm{~d}$ and $6 \mathrm{~d}$-refrigerated raw milk (YS6) by fermentation time. C6; yogurt made by uninoculated raw milk during $6 \mathrm{~d}$, YS6; yogurt made by inoculated raw milk during $6 \mathrm{~d}$ with Serratia liquefaciens (match \%: 99.39) as $10^{5} \mathrm{CFU} / \mathrm{mL}$.

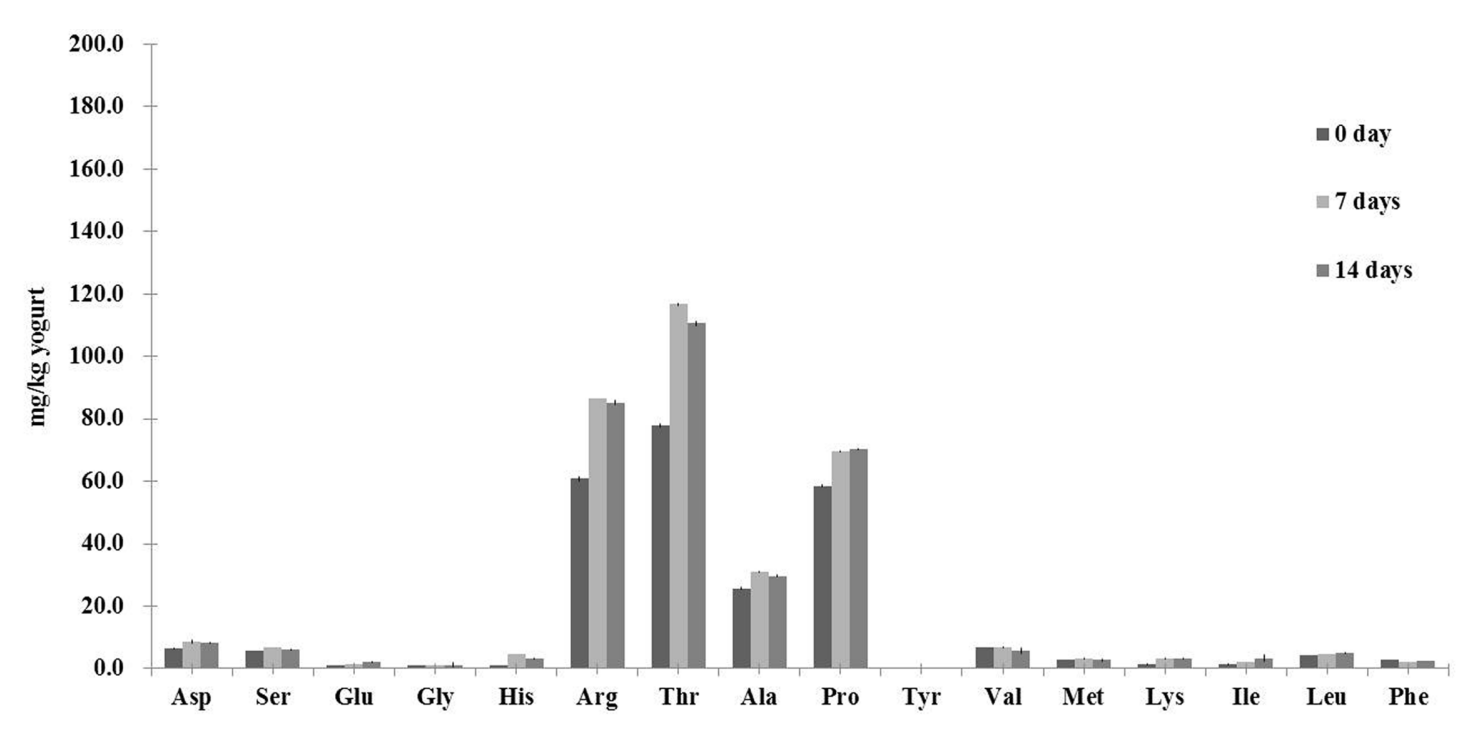

Free Amino Acids

Fig. 5. Concentration of free amino acids in yogurt made with pasteurized raw milk. Asp; aspartic acid, Ser; serine, Glu; glutamic acid, Gly; glycin, His; histidine, Arg; arginine, Thr; threonine, Ala; alanine, Pro; proline, Cys; cysteine, Tyr; tyrosine, Val; valine, Met; methionine, Lys; lysine, Ile; isoleucine, Leu; leucine, Phe; phenylalanine. 


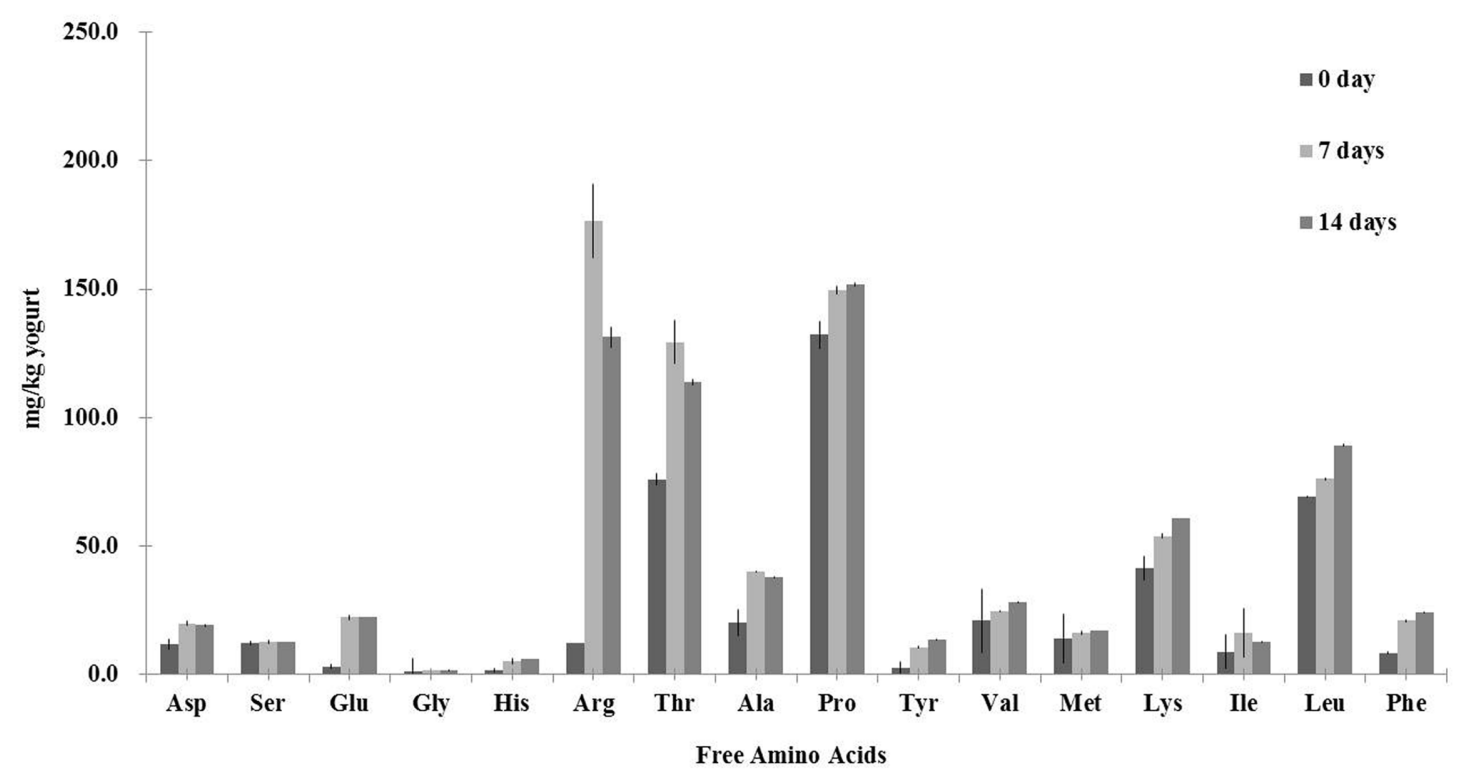

Fig. 6. Concentration of free amino acids in yogurt (YS6) made with inoculated raw milk. Asp; aspartic acid, Ser; serine, Glu; glutamic acid, Gly; glycin, His; histidine, Arg; arginine, Thr; threonine, Ala; alanine, Pro; proline, Cys; cysteine, Tyr; tyrosine, Val; valine, Met; methionine, Lys; lysine, Ile; isoleucine, Leu; leucine, Phe; phenylalan.

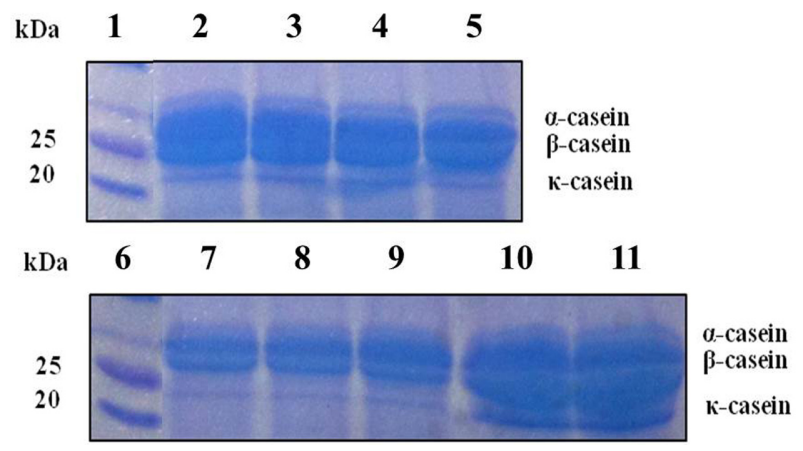

Fig. 7. SDS-PAGE patterns of casein from yogurt made with inoculated raw milk by refrigerated days. Lane 1,6 ; prestained molecular mass standard, lane $2,3,4,5$; casein from yogurt made with $0,9,14,21$ d-refrigerated raw milk $3 \mathrm{~d}$ after inoculated by Serratia liquefaciens (match \%: 99.39) as $1 \times 10^{5} \mathrm{CFU} / \mathrm{mL}$, lane $7,8,9$; casein from yogurt made with $0,10,14$ days-refrigerated raw milk $6 \mathrm{~d}$ after inoculated by Serratia liquefaciens (match \%: 99.39) as $1 \times 10^{5} \mathrm{CFU} / \mathrm{mL}$, lane 10 ; pasteurized milk, lane 11 ; uninoculated raw milk.

of dairy products may be affected by heat-resistant enzymes that are secreted by psychrotrophs in raw milk before heat treatment or by enzymes and other metabolites that are produced by psychrotrophs growing during the cold storage (Sørhaug and Stepaniak, 1997). These enzymes and other metabolites are responsible for bitter, fruity, and 'dirty' flavors as well as rancid and soapy flavors (Bigalke, 1985; Cousin and Marth, 1977; Dumont et al., 1977;
Law et al., 1976; Pinheiro et al., 1965; Reiter et al., 1967; White and Marshall, 1973).

YS3 and YS6 were inoculated with different concentrations of Serratia liquefaciens, but SDS-PAGE showed no significant difference in casein band size during the cold storage period although the degradation of casein in YS6 was much more than YS3. It should be noted that heat treatment of mix before the inoculation of the starter culture was done, which caused the death of psychrotrophic bacteria and inhibited enzyme activity.

\section{Conclusion}

This study investigated the effect of proteolytic (Serratia liquefaciens, match \%: 99.39) or lipolytic (Acinetobacter genomospecies 10, match \%: 99.90) psychrotrophic bacteria on the microbial and chemical properties of yogurt during storage. The short chain free fatty acids content among FFA in yogurt with Acinetobacter genomospecies 10 increased dramatically, and Serratia liquefaciens in yogurt caused a fast accumulation of free amino acids, especially bitter peptides such as leucine, valine, arginine, and tyrosine. Our study demonstrates that raw milk containing psychrotrophic bacteria can produce these excessive peptides and FFA in yogurt, which could develop off-flavors that deteriorate the quality of commercial yogurt products. 


\section{References}

1. Adams, D., Barach, J., and Speck, M. (1976) Effect of psychrotrophic bacteria from raw milk on milk proteins and stability of milk proteins to ultrahigh temperature treatment. $J$. Dairy Sci. 59, 823-827.

2. AOAC (2007) Official methods of analysis. 18th ed, Association of Official Analytical Chemists, Washington DC, pp. 68-81.

3. Bigalke, D. (1985) Lipolytic and proteolytic microorganisms and their enzymes. II. Dairy and Food Sanitation 5, 388-389.

4. Cousin, M. (1982) Presence and activity of psychrotrophic microorganisms in milk and dairy products: a review. $J$. Food Prot. 45, 172-207.

5. Cousin, M. and Marth, E. (1977) Cheddar cheese made from milk that was precultured with psychrotrophic bacteria. $J$. Dairy Sci. 60, 1048-1056.

6. De Jong, C. and Badings, H. T. (1990) Determination of free fatty acids in milk and cheese procedures for extraction, clean up, and capillary gas chromatographic analysis. J. High Resolut. Chromatogr. 13, 94-98.

7. Deeth, H. (2002) Lipolysis in milk and dairy products: a research journey. Food Aust. 54, 433-436.

8. Dumont, J., Delespaul, G., Miguot, B., and Adda, J. (1977) Influence des bactéries psychrotrophes sur les qualités organoleptiques de fromages à pâte molle. Le Lait 57, 619-630.

9. Hong, J. L. (1994) Determination of amino acids by precolumn derivatization with 6-aminoquinolyl-N-hydroxysuccinimidyl carbamate and high performance liquid chromatography with ultraviolet detection. J. Chromatogr. A. 670, 59-66.

10. Ingraham, J. (1962) Temperature relationships. The Bacteria 4, 265-296.

11. Ingraham, J. and Stokes, J. (1959) Psychrophilic bacteria. Bacteriol. Rev. 23, 97-108.

12. Iwasaki, T. and Kosikowski, F. V. (1973) Increasing flavor in cheese with commercial microbial enzyme preparations. $J$. Dairy Sci. 56, 623-624.

13. Laemmli, U. K. (1970) Cleavage of structural proteins during the assembly of the head of bacteriophage T4. Nature 227, 680-685.

14. Law, B., Sharpe, M. E., and Chapman, H. R. (1976) The effect of lipolytic Gram-negative psychrotrophs in stored milk on the development of rancidity in Cheddar cheese. J. Dairy Res. 43, 459-468.
15. Mikolajcik, E. (1979) Psychrotrophic bacteria and dairy product quality. 1. Major organisms involved and defects produced. Cult. Dairy Prod. J. 14, 6-10.

16. Pinheiro, A., Liska, B., and Parmelee, C. (1965) Heat stability of lipases of selected psychrophilic bacteria in milk and Purdue Swiss-type cheese. J. Dairy Sci. 48, 983-984.

17. Reiter, B., Fryer, T., Pickering, A., Chapman, H. R., Lawrence, R., and Sharpe, M. E. (1967) The effect of the microbial flora on the flavour and free fatty acid composition of Cheddar cheese. J. Dairy Res. 34, 257-272.

18. Serra, M., Trujillo, A., Pereda, J., Guamis, B., and Ferragut, V. (2008) Quantification of lipolysis and lipid oxidation during cold storage of yogurts produced from milk treated by ultra-high pressure homogenization. J. Food Eng. 89, 99104.

19. Shelley, A., Deeth, H., and Macrae, I. (1986) Growth of lipolytic psychrotrophic pseudomonads in raw and ultra-heattreated milk. J. Appl. Microbiol. 61, 395-400.

20. Shin, Y. K., Oh, N. S., Lee, H. A., and Nam, M. S. (2013) Effects of psychrotrophic bacteria Acinetobacter genomospecies 10 and Serratia liquefaciens on raw milk quality. Korean J. Food Sci. An. 33, 542-548.

21. Sørhaug, T. and Stepaniak, L. (1997) Psychrotrophs and their enzymes in milk and dairy products: quality aspects. Trends Food Sci. Tech. 8, 35-41.

22. Stead, D. (1986) Microbial lipases: their characteristics, role in food spoilage and industrial uses. J. Dairy Res. 53, 481505.

23. Stokes, J. (1963) In Recent Progress in Microbiology, Canada, University of Toronto Press, 8, 187-192.

24. Thomas, S. (1966) Sources, incidence and significance of psychrotrophic bacteria in milk. Milchwissenschaft 21, 270-275.

25. Thomas, S. and Thomas, B. F. (1973) Psychrotrophic bacteria in refrigerated bulk-collected raw milk. Part I. Dairy Ind. 38, 11-15.

26. Wessels, D., Jooste, P. J., and Mostert, J. F. (1988) The occurrence and importance of enterobacteriaceae isolates in milk and dairy products. S. Afr. J. Dairy Sci. 20, 23-28.

27. White, C. and Marshall, R. (1973) Reduction of shelf-life of dairy products by a heat-stable protease from Pseudomonas fluorescens P26. J. Dairy Sci. 56, 849-853.

28. Witter, L. D. (1961) Psychrophilic bacteria-a review. J. Dairy Sci. 44, 983-1015.

(Received 2014.5.21/Revised 2014.8.4/Accepted 2014.8.5) 